\title{
Power Generation from Industrial Waste Material using Silhouete
}

\author{
Ch. Santoshkumar, G. Chandra sekhar,
}

\begin{abstract}
This paper presents the thought of biogas primarily based power plants for the wants of rural electrification by using industrial byproducts. The bio gas can be produced in industries by using an anaerobic digestion process of industry waste materials during the productionof its output from waste materials such aswater, animal dung etc. The specially designed gas engines with the modified continuous operation are used to separate the waste materials. The firing controllers for sparking different sectionsareused to burn the gas .this work is done at III Vijayanagarbiotech pvt Ltd, vizianagaram, Andhra pradesh. The gas engine is coupled to the alternator to produce the electrical energy of 1.2 MW. The demand forelectricitycan be met by developing this kind of process. If the excess bio gas is available, which can be used for generation of more electricity.

Index Terms-Biogas, rural electrification, Anaerobic digestion, Waste heat recovery, Biogas generators.
\end{abstract}

\section{INTRODUCTION}

The waste management is the waste of assortment, process and disposal managing and observance of waste materials. If the commercial product of waste product, whether or not they are processed, wastewater, compoundingwaste product. If the industrial product of waste material, whether they are processed, wastewater, mixing waste material, waste heat and waste of gases the management. Energy will be derived from waste that has been treated and ironed into waste of product, waste that has been regenerate into biogas or heat and steam from waste that has been incinerated. Waste to energy technologies that produces fuels are referred to waste to fuel technologies. I am process the key chance for the biogas production in trade, which may be the higherresolution for electrification issues of trade own generation. numerouskinds of anaerobic digestion plants will bemadesupported the daily availableness of raw materials. the choicekinds of digesters, engines, generators are tonality points within the installation of the biogas primarily based power plants [1].

\section{SOURCES OF BIO GAS PRODUCTIONS}

\section{A. Production wastages of industry:}

In industry can be production of waste of water to heat and mixing with lime power (calcium carbonate and water) stored in mixing tank. Both are oxidization with motor using of the machine. Those water and calciumhydroxide mixing in the tank.

\section{B. Chemicals:}

Calcium carbonate + water $\rightarrow$ calcium hydroxide

Revised Manuscript Received on April 12, 2019.

Ch. Santoshkumar,PG student, Dept.of EEE, GMRIT, Rajam, Andhra Pradesh, India. (E-mail: chippadas707@gmail.com)

G. Chandra sekhar,Professor,Dept.of EEE, GMRIT, Rajam, Andhra Pradesh, India..(E-mail: chandrasekhar.g @ gmrit.org)

\author{
$\mathrm{CaCo}_{3}+\mathrm{H}_{2} \mathrm{O} \rightarrow \mathrm{Ca}(\mathrm{OH})_{2}$ \\ C. Cow dung:
}

The dung is used for in case if plant processing is suddenly stopped some few days. So the bacteria will die. And again the bacteria will be generated propose only.

\section{METHODS FOR BIO GAS PRODUCTION}

There are variedprocesskindout there in biogas production primarily basedbusinessmistreatmentcapability of power generated some want of conductivity throughout the process methodologies digests will be designed for our plant [2] . during this chapter varied is given of anaerobic digestion and therefore the main induces on this method.

\section{A. Anaerobic digestion:}

Thebacteria which are living growth in the process of the absence of air. In this process of the chemicals and waste water mixed results in formation of bio gas. A few days after 4-5 days produced carbon dioxide and bacteria produced in this process is called "design affecting"and then the bio gas produced in the digester methane gas this process is called N-butane.

\section{B. Products :}

The autoclave in can produces biogas and digestate. The biogas consists of main elementsalkane series (CH4) fifty five - sixtieth and $\mathrm{CO} 2$ ( greenhouse emission ) fortieth, touch of gas $(\mathrm{N})$ and is saturated with water $(\mathrm{H} 2 \mathrm{O})$. the most important polluting component is sulphide (H2S).

\section{Design parameters consideration for digester:}

The following table contains the main design parameters for the digestive system as shown in table 1 below.

Table 1:

\begin{tabular}{|c|c|c|}
\hline Parameters & Desired value & Unit \\
\hline Digestion volume & 4500 & $\mathrm{M}^{\wedge} 3$ \\
\hline Residence time & $<10$ & Days \\
\hline Temperature & $50-60$ & ${ }^{\circ} \mathrm{c}$ \\
\hline Maximum & $3-4$ & ${ }^{\circ} \mathrm{c}$ \\
\hline
\end{tabular}

\section{GAS SYSTEM DESIGN}




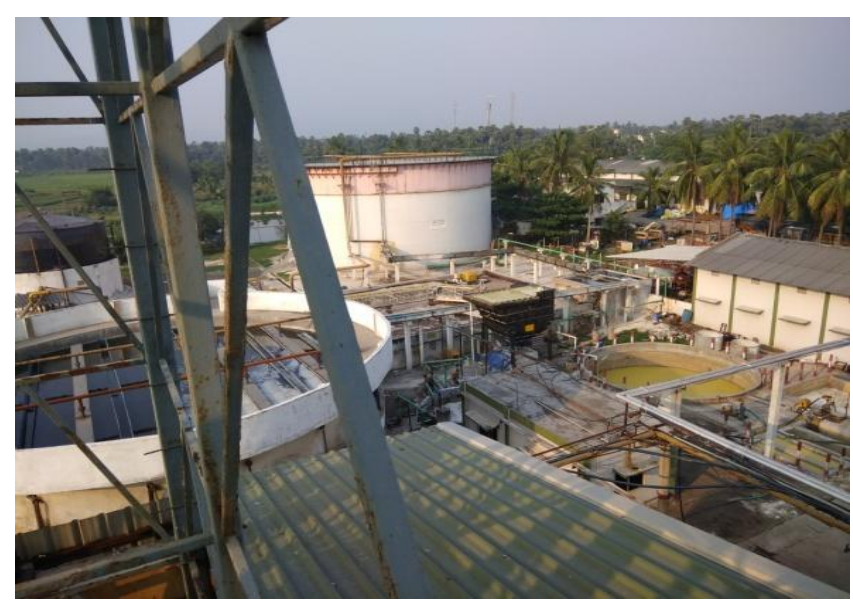

Fig(1).Plant ETP process

The operate of this item is to store the manufacture bio gas.. The plant consists of digested balloon to top of the digester and gas piping from the digester to a gas storage tank of gas storage tank to his engine.

The gas storage foil has a water lock aroundthe disaster which will present air pressure build-up the remain wastage the under the water. The small particles can float on water. The waste water can remain outer pump the sludge can remain produce the bio gas [3] [4] .

Within the gas piping, 2 waters condensed vessels are put in. These are necessary as a result of the biogas are going to be saturated with water at the autoclave temperature and condensationcan from outside autoclave as shown in fig one. Since if are going to be colder there. The condensationhas got to be faraway from the bio gas before the engine.

Bio gas power plant capacity

\section{Table 2}

\begin{tabular}{|l|l|}
\hline Bio gas power plant & $500 \mathrm{~m}^{\wedge} 3$ \\
\hline Power generation capacity & $1.2 \mathrm{MW}$ \\
\hline Hot air generation & $6620 \mathrm{~kg} / \mathrm{h}$ \\
\hline Hot air temperature & $480^{\circ} \mathrm{c}$ \\
\hline Methane in bio gas & $55-60 \%$ \\
\hline sulfur recovery & $120 \mathrm{~kg} / \mathrm{day}$ \\
\hline ETP reactor capacity & $4500 \mathrm{~m}^{\wedge} 3$ \\
\hline Flow of effluent & $20 \mathrm{~m}^{\wedge} 3$ \\
\hline Cod input & $35000 \mathrm{mg} / \mathrm{lt}$ \\
\hline Cod output & $<200 \mathrm{mg} / \mathrm{lt}$ \\
\hline
\end{tabular}

\section{A. Filtering of excess bio gas}

The digester out exachuast valve pump to the biogas and water can be flows the pump. The water can be separate through the pump the gas in flows though the gas storage holder. The gas storage holder to the pre scrubber and scrubber pumps $f$ with mixed chemical are spray of gas. They will be some waste sludge can be down the scrubber tank [5].

The scrubber tank to gas wash column with chemicals and water can be wash $\mathrm{f}$ bio gas. The chemical are ( EDTA, peracloride and soda ash). The waste water can be washed he water tank to regenerative tank of chemicals.

\section{B. Remove the sludge:}

After he bio gas generation the solid sludge will forms under the digesters. He remaining sludge of chemical are purification, filtration of gas using for filter trays. He bio gas sludge removes he sulfur completely removable as shown in fig 2 . The code input of digester safe recovery $120 \mathrm{Kg} /$ day in the form of cake filter trays [6].

After separate the sulfur is used for against production material are used in the industry this process complete recycling process the plants.

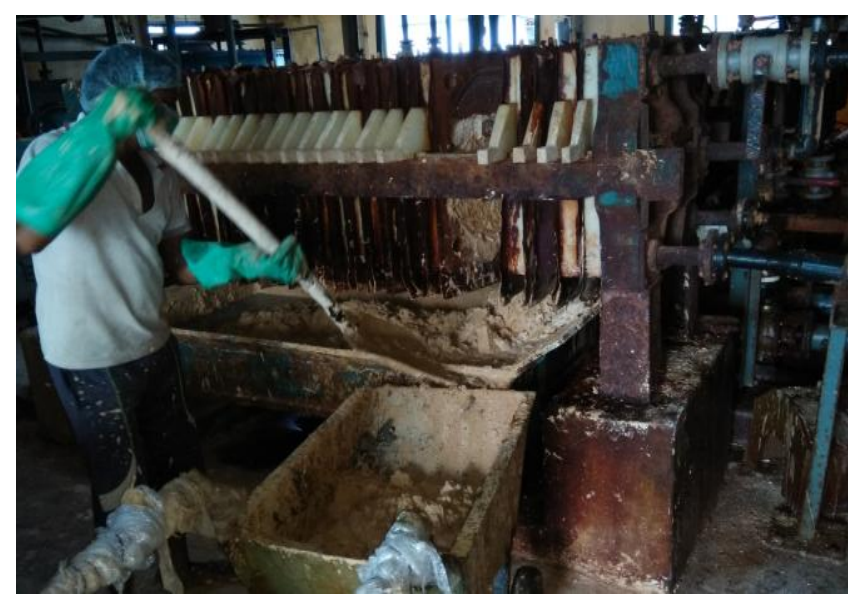

Fig(2). Filter tray, removing sulfur

C. Biogas flow chart
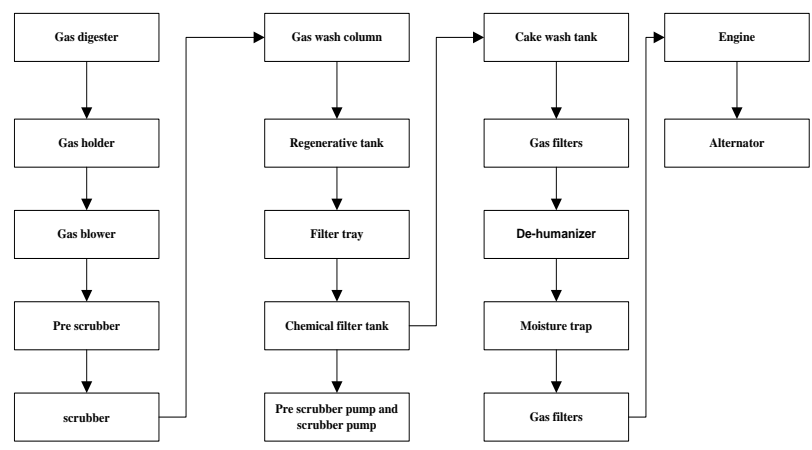

\section{DESIGN OF GENSET\& RESULTS}

The genset means the engine and alternator coupled in directly. Especially design requirements which are bio gas filtration with nature of gas and firing point. Calorificvalue of fuel. The number of cylinders is configuration o sections are designed section A and section B. So the section numbers of The gas engine is equipped with sensors for watching and management purpose. The sensors are wired to a multifunction rail at cylinder rows $\mathrm{A}$ and $\mathrm{B}$. A bus cable runs from every multifunction rail to TEM system. At the engine all componentseager to be grounded are connected the copper rail this rule shouldthus be connected to the factor system of the switch gear .an summary of the watching facilities is shown within the following engine drawings. The engine is likewise equipped with driving and management sensors. These wired to a terminal box on the genset. 


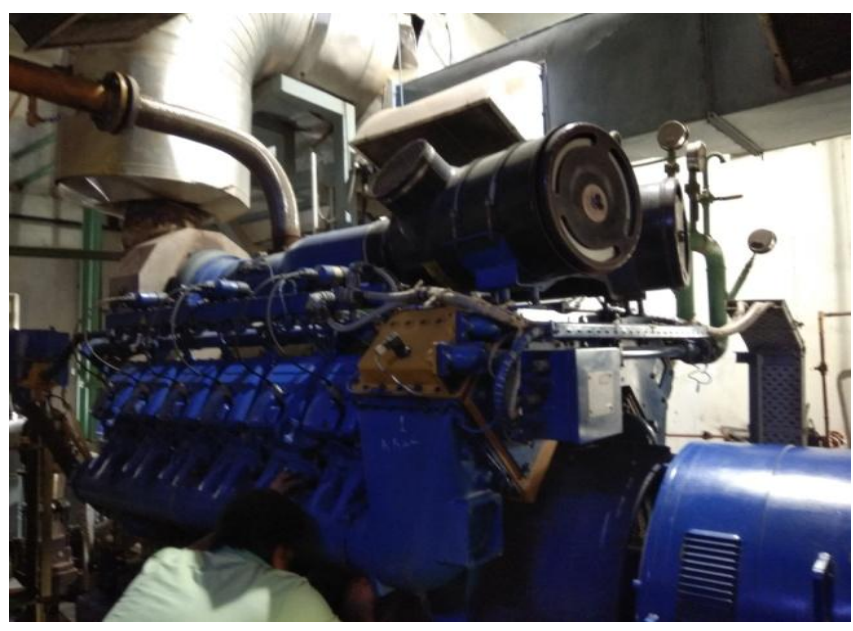

Fig(3).Gas engine

Added in away by one of the firing cylinders of the engine.

\section{A. Monitoring and cabling: Engine}

The ICEis supplied with sensors for watching and management purpose. The sensors are wired to a multifunction rail at cylinder rows $\mathrm{A}$ and $\mathrm{B}$. A bus cable runs from every multifunction rail to TEM system as shown in fig three. At the engine all componentseager to be grounded are connected the copper rail this rule shouldthus be connected to the factor system of the switch gear. an summary of the watching facilities is shown within the following engine drawings. The engine is likewise equipped with driving and management sensors. These wired to a terminal box on the genset.

\section{B. Alternator:}

The categories used as commonplace brushless synchronous generators that, betting on the appliance could also be appropriate for main parallel or back-up power operations. betting on output and therefore the out there main offer these could also be $440 \mathrm{~V}-669 \mathrm{~V}$ three phase generator. $3 \mathrm{KV}-15 \mathrm{KV}$ medium voltage generators there is supply output using in industry main bus bar circuit panels as shown in fig 4 .

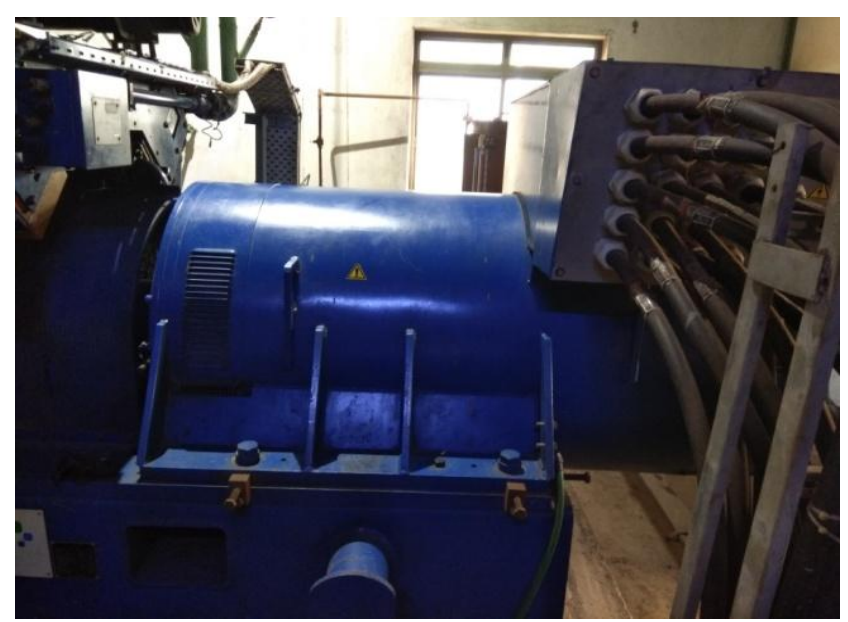

Fig(4). Alternator

\section{CONCLUSION:}

This paper gives the idea for the industry using his own he generation of the power and then using production wastages with on process of bio gas produced than the bio gas filter some reduced the sulfur. The biogas can be used in electricity generated by the plant and again the sulfur can be don't waste the material. Can be used in the production of material in the industry their process is completely recycled process of the plant. There is no fuel cost and no need for man power, no waste of time. The production completely continuousrun the industry.

\section{REFERENCES:}

1. Elango, R. A., \& Mohan, P. (2014, March). "Bio-gas power plants-Green energy options for Indian villages". "2014 International Conference on Green Computing Communication and Electrical Engineering(ICGCCEE)" DOI: 10.1109/ICGCCEE.2014.6922457, pp. 1-3.

2. Lardinois, I., and Klundert, A van de, Organic Waste Options for Small-scale Resource Recovery. Urban Solid Waste Series, TOOL/WASTE Consultants, 1993.

3. Zhang Bo ; Sch. of Manage., Beijing Union Univ., Beijing, China; Chen Hongbo Research on Chinese Household or Livestock Farms Biogas Practical Energy Technologies.

4. Daniel J.Stepan, Richard E.Shockey, Thomas A.Moe, Ryan Dorn, Subtask2.3-Carbon Dioxide Sequestering Using Microalgal Systems.2002.

5. ChunMeiGao, "Biogas Power Generation and Waste Heat Utilization, "Urban Management and Technology 2rd ed., vol. 7. pp. 217-219, 2005. 